\title{
Correction to: Concurrent validity and reliability of measuring range of motion during the cervical flexion rotation test with a novel digital goniometer
}

Kerstin Luedtke ${ }^{1,2^{*}}$, Thomas Schoettker-Königer ${ }^{3}$, Toby Hall ${ }^{4}$, Christine Reimer ${ }^{5}$, Maike Grassold ${ }^{5}$, Petra Hasselhoff-Styhler ${ }^{3}$, Christian Neulinger ${ }^{3}$, Max Obrocki ${ }^{5}$, Philipp Przyhoda ${ }^{3}$ and Axel Schäfer ${ }^{3}$

\section{Correction to: BMC Musculoskelet Disord 21, 535 (2020)} https://doi.org/10.1186/s12891-020-03525-6

Following publication of the original article [1], the authors noticed that one of the co-authors' name is incorrect. The author Christine Enns should be changed to Christine Reimer. The original article [1] has been updated.

\begin{abstract}
Author details
'Laboratory of Pain Research, Institute of Physiotherapy and Health Sciences, The Jerzy Kukuczka Academy of Physical Education, Katowice, Poland. ${ }^{2}$ Institute of Health Sciences, Academic Physiotherapy, University of Luebeck, Lübeck, Germany. ${ }^{3}$ Faculty of Social Work and Health, University of Applied Science and Art (HAWK), Goschentor 1, 31134 Hildesheim, Germany. ${ }^{4}$ School of Physiotherapy and Exercise Science, Curtin University, Perth, WA, Australia. ${ }^{5}$ Faculty of Social Sciences, University of Applied Sciences Bremen, Neustadtswall 30, 28199 Bremen, Germany.
\end{abstract}

Published online: 21 September 2020

\section{Reference}

1. Luedtke K, Schoettker-Königer T, Hall T, et al. Concurrent validity and

reliability of measuring range of motion during the cervical flexion rotation test with a novel digital goniometer. BMC Musculoskelet Disord. 2020;21:

535. https://doi.org/10.1186/s12891-020-03525-6.

The original article can be found online at https://doi.org/10.1186/s12891020-03525-6.

* Correspondence: Kerstin.luedtke@uni-luebeck.de

'Laboratory of Pain Research, Institute of Physiotherapy and Health Sciences, The Jerzy Kukuczka Academy of Physical Education, Katowice, Poland

${ }^{2}$ Institute of Health Sciences, Academic Physiotherapy, University of Luebeck, Lübeck, Germany

Full list of author information is available at the end of the article

C The Author(s). 2020 Open Access This article is licensed under a Creative Commons Attribution 4.0 International License, which permits use, sharing, adaptation, distribution and reproduction in any medium or format, as long as you give appropriate credit to the original author(s) and the source, provide a link to the Creative Commons licence, and indicate if changes were made. The images or other third party material in this article are included in the article's Creative Commons licence, unless indicated otherwise in a credit line to the material. If material is not included in the article's Creative Commons licence and your intended use is not permitted by statutory regulation or exceeds the permitted use, you will need to obtain permission directly from the copyright holder. To view a copy of this licence, visit http://creativecommons.org/licenses/by/4.0/. The Creative Commons Public Domain Dedication waiver (http://creativecommons.org/publicdomain/zero/1.0/) applies to the data made available in this article, unless otherwise stated in a credit line to the data. 